\title{
NUTRITIONAL COMPOSITION, IN VITRO GAS PRODUCTION AND IN SACCO DEGRADABILITY OF PROCESSED Croton megalocarpus NUTS FOR RUMINANT FEEDING
}

\author{
Elias KABOCHI NJOROGE, Caroline CELINA WAMBUI ${ }^{\circledR \otimes}$ and Chrilukovian BWIRE WASIKE \\ Livestock Efficiency Enhancement Group (LEEG), Department of Animal Science, School of Agriculture \& Food Security, Maseno \\ University, P.O. Private Bag, 40105, Maseno, Kenya \\ Email: wambuicc@gmail.com; (D) ORCiD: 0000-0002-0007-3096 \\ Supporting Information
}

\begin{abstract}
This study was conducted to evaluate the effects of processed croton nut on chemical composition, in vitro gas production and in sacco degradability. Four forms of croton nut namely: whole nut (WN), peeled nut (PN), De-husked nut (DhN) and De-fatted seed (DfS) were subjected to proximate analysis, Van Soest fibre fractionation, mineral composition analysis, phytochemical and aflatoxin tests. Degradability analyses were conducted using in vitro gas production and in sacco degradability techniques. Defatted seeds recorded significantly high level of CP and NFE $(198 \mathrm{~g} / \mathrm{kg}$ and $174 \mathrm{~g} / \mathrm{kg})$, whereas, ash content and ether extract (EE) were significantly high in WN $(59 \mathrm{~g} / \mathrm{kg})$ and $\mathrm{DhN}(362 \mathrm{~g} / \mathrm{kg})$ respectively. Low fibre fractions of NDF (556 g/ kg) and ADF (490 g/ kg) were observed in DhN, while the mineral content was high in DfS which had calcium at $2.13 \mathrm{~g} / \mathrm{kg}$ and phosphorus at $5.04 \mathrm{~g} / \mathrm{kg}$. High level of flavonoid was recorded in WN (124 $\mathrm{g} / \mathrm{kg}$ ), whereas low level of alkaloids was found in DfS $(60 \mathrm{~g} / \mathrm{kg})$ and tannins in PN $(7.1 \mathrm{~g} / \mathrm{kg})$. The potential in vitro gas production $(a+b)$ was highest in DfS $(22.2 \mathrm{ml} / 0.2 \mathrm{gDM})$ while potential in sacco degradability $(a+b)$ was highest in DhN (58.4\%). High level of organic matter digestibility (OMD) (41 \%) was observed in DfS. At $k p=0.025$ rumen outflow rate, $\mathrm{DhN}$ had the highest effective degradability of dry matter $(56.6 \%)$, while the rate effective crude protein degradability was $80.0 \%$. Processing through peeling and dehusking improved the protein, energy and mineral content of DhN and DfS while crude fibre content reduced. Nutritional composition and degradability characteristics of all forms of croton nuts imply that they could be used in a total mixed ration (TMR) to supply requisite nutrients for maintenance of ruminant animals, while $\mathrm{DhN}$ and DfS could be used to supplement energy and protein for increased productivity.
\end{abstract}

Keywords: Chemical composition, Croton nut, degradability, Gas production technique, Processing.

Abbreviations: WN: whole nut; PN: peeled nut; DhN: dehusked nut; DfS: defatted seeds

\section{INTRODUCTION}

The livestock sector accounts for $40 \%$ of agriculture's Gross Domestic Product (GDP) in developing countries and is not only a source of food and livelihood but enhances resilience against climate change extremities such as drought (Herrero et al., 2013; Nabarro and Wannous, 2014). The continuously growing human population as well as increased per capita income has led to increased demand for livestock-based products (Otte et al., 2019). Thus, livestock production ought to increase so as to meet the rising demand. Ruminant animals in tropical arid and semi-arid areas (ASAL) continue to play a key role of the rural households in developing countries where they are a major source of nourishment from products such as meat and milk as well as play social economic roles by providing income and acting as an economic safety net (Herrero et al., 2013).

Livestock production in the tropics is constrained by various factors which include inadequate nutrition, breeding and reproduction, disease and parasites among others (Kahi and Wasike, 2019). In confined systems, feeds account for up to $70 \%$ of the total cost of production (Makkar, 2014). Hence, variation in quantity and quality of feeds becomes a major constraint to livestock production. The problem of feed scarcity is further exacerbated by increased food - feed competition between human and livestock and decline in available land for feed production. Majority of ruminant animals (cattle, sheep and goats) in Kenya are reared in arid and semi-arid Counties (KNBS, 2019). In these areas, effects of climate change such as drought greatly reduces available feed resources consequently leading to low productivity and at time causing mortality of the animals (Makkar, 2014). Feeding strategies that optimise utilisation of available feed resources are thus critical to maintain ruminant productivity and preventing mortality.

Identification and introduction of alternative feed resources is a major avenue that could be used to mitigate feed scarcity. Locally available, low-cost feed resources could enhance resilience and adaptability of small holder farmers and pastoralists by allowing them to transit through adverse effects of climate change (Makkar, 2014). Evaluation of nonconventional feed resources for potential inclusion in mainstream livestock offers a preliminary step in determining the suitability of the identified feed resource before it can be included in livestock diets (Quansah and Makkar, 2012). One 
such feed with potential is croton nuts from Croton megalocarpus tree. Croton tree is adapted to different agro-ecological zones in the tropics and has multipurpose use such as provision of wood fuel, acting as a live fence and a source of bio fuel (Ndegwa et al., 2011). Croton tree produces up to $25 \mathrm{~kg}$ of nuts per year (Jacobson et al., 2018) which are reported to contain high CP content of up to $18 \%$, crude fat (30\%) and hence could be exploited for feeding livestock (Thijssen et al., 1996; Ndegwa et al., 2011). Farmers have been observed to collect and use croton nuts for feeding cows and goats during extreme dry seasons. However, there is limited information on the chemical composition, ant - nutritive factors and degradability of croton nuts. Moreover, there is also limited information on effects of processing various forms of croton such as peeling, dehusking and oil extraction on the nutritive value for effective utilization of this underutilized feed resource. This study was therefore conducted to evaluate nutritional and phytochemical composition and ruminal degradation of the various processed forms of croton nut to facilitate its use in ruminant feeding.

\section{MATERIALS AND METHODS}

\section{Site description}

Samples of Croton nut were collected from Laikipia West and East sub counties of Laikipia County, which is located North - West of Mount Kenya at an altitude of between $1600 \mathrm{~m}$ and $2300 \mathrm{~m}$ above sea level with a total area of 9,700 $\mathrm{km}^{2}$. The area experiences a bimodal rainfall pattern with long rains between March and June and short rains between October and December separated by dry seasons (MoALF, 2017). The annual precipitation varies between $400 \mathrm{~mm}$ to $900 \mathrm{~mm}$ and average temperature is between $16^{\circ} \mathrm{C}$ and $26^{\circ} \mathrm{C}$. The area lies in semi - humid, semi - arid, arid to very arid agro ecological zones IV - VII, and is considered arid and semi-arid (ASAL) (MoALF, 2017).

\section{Collection and processing of croton nuts}

Mature croton nuts were collected from the ground, air dried under shade and processed into four forms which included whole nuts (WN), peeled nut (PN), dehusked nut (DhN) and defatted seeds (DfS). The whole nuts (WN) form comprised of unprocessed whole croton nuts with the outer peel (exocarp) and the hard woody husk (endocarp) intact. Peeled nuts (PN) consisted of nuts whose outer seed coat (peel/exocarp) was removed leaving the hard woody endocarp intact. De-husked nuts (DhN) consisted of the inner seeds after the removal of both the outer peel (exocarp) and the hard woody husk (endocarp). Defatted seeds (DfS) also referred to as Croton cake was the by-product of the seeds after oil extraction using a cold press. The DfS form was obtained from a commercial plant that extracts bio-diesel from croton in Laikipia County. After processing into various forms, the samples were then ground using a hummer mill to pass through a $2 \mathrm{~mm}$ screen and stored in air tight glass containers pending analyses.

\section{Chemical analyses}

Ground samples of the various processed forms of croton were subjected to proximate analysis to determine dry matter (DM), ash, crude fibre (CF), ether extract (EE) and crude protein (CP) which were expressed on dry matter basis according to AOAC (1990). Nitrogen free extract (NFE) was calculated as the difference of the sum (\%) of crude protein, crude fibre, ether extract and total ash from 100\%. Neutral detergent fibre (NDF), acid detergent fibre (ADF) and acid detergent lignin (ADL), were sequentially determined using the method of Van Soest et al. (1991). Hemicellulose content was calculated as the difference between NDF and ADF, whereas cellulose was the difference between ADF and ADL. Gross energy $(\mathrm{MJ} / \mathrm{kg}$ ) was determined from $0.5 \mathrm{~g}$ of sample using a digital bomb calorimeter (CAL2K of Digital Data Systems (pty) Itd South Africa). Neutral detergent insoluble nitrogen and acid detergent insoluble nitrogen were determined from the residues of NDF and ADF using Kjeldahl method (AOAC, 1990). Nitrogen obtained was multiplied with a conversion factor (6.25) to obtain neutral detergent insoluble crude protein (NDICP) and acid detergent insoluble crude protein (ADICP).

Sodium ( $\mathrm{Na}$ ) and potassium $(\mathrm{K})$ concentration was determined using atomic emission in a flame photometer while total available phosphorus (P) concentration was determined using Ultra Violet (UV) colorimeter (AOAC, 1990). Calcium (Ca), magnesium (Mg), iron (Fe), zinc $(\mathrm{Zn})$, manganese $(\mathrm{Mn})$ and copper $(\mathrm{Cu})$ concentrations were determined using an atomic absorption spectrophotometer (AAS) (AOAC, 1990).

\section{Phytochemicals and aflatoxin analyses}

Flavonoids were extracted from the samples using organic solvents and expressed gravimetrically as outlined by Harbone (1984). Alkaloid determination was done by extraction from the samples using acetic acid dissolved in ethanol (Harbone, 1984). Tannin content was determined using Folin-Coicalteu reagent and determination of absorbance was done at $725 \mathrm{~nm}$ using a UV-visible spectrophotometer (AOAC, 1990). Aflatoxins were extracted using methanol and levels determined by ELISA testing kit. The amount of aflatoxin was expressed in parts per billion (ppb) calculated from the standard aflatoxin curve (Leszczyñska et al., 2001).

\section{In vitro gas production}

In vitro gas procedure was conducted following the procedure of Menke and Steingass (1988). Rumen liquor was drawn in the morning from two mature fistulated Friesian steers. The steers had $450 \pm 25 \mathrm{~kg}$ live weight and were fed on Rhodes grass (Chloris gayana) hay and wheat bran at $90 \%$ and $10 \%$ respectively of the total ration at $3 \%$ of their body 
weight at 08:00 hours and 17:00 hours for maintenance purposes. Mineral licks and water were provided adlibitum. This was done so as to maintain a stable rumen environment before the rumen liqour was collected. Collected rumen liqour was strained through four layers of cheese cloth into a pre-warmed, vacuum flask and kept at $39^{\circ} \mathrm{C}$ under $\mathrm{CO}_{2}$ atmosphere. About $0.2 \mathrm{~g}$ of $1 \mathrm{~mm}$ ground samples (WN, PN, DhN and DfS) were weighed into the glass syringes. A mixture of $30 \mathrm{ml}$ of rumen liquor and buffer in the ratio of 1:2 was added into each of the $100 \mathrm{ml}$ calibrated glass syringes that were pre-warmed to $39^{\circ} \mathrm{C}$. Oil was applied to the pistons to facilitate ease of movement and prevent gas escape. Two blank syringes with rumen liquor without a feed sample were included as controls. All syringes were incubated in a water bath maintained at $39^{\circ} \mathrm{C}$ and shook periodically. Gas production readings were recorded at 0 and after $3,9,12,24,48$, 72 and 96 hours of incubation.

The gas production characteristics were computed by fitting the mean gas volumes to the exponential equation of Ørskov and Mcdonald (1979) using Neway Excel Computer program (Chen X. B., Rowett Research Institute, Aberdeen UK).

$Y=a+b\left(1-e^{-c t}\right)$

(Ørskov and Mcdonald, 1979)

Where: $Y$ is gas production $(\mathrm{ml} / 0.2 \mathrm{~g})$ at time $t$, $a$ is gas production $(\mathrm{ml})$ from immediately soluble fraction, $b$ is gas production $(\mathrm{ml})$ from insoluble fraction, $a+b$ is gas production from potential degradable fraction, $c$ is the rate constant of gas production per hour $(h), t$ is the incubation time in hours and $e$ is the exponential constant (2.718).

In vitro gas production parameters were used to estimate organic matter digestibility (OMD), metabolisable energy

(ME), Dry Matter intake (DMI) and short chain fatty acids (SCFA) using the models presented in Equations 2 to 5.
$O M D(\%)=14.88+0.889 G V+0.45 C P+0.0651 X A$
(Menke and Steingass, 1988)
(Makkar and Becker, 1996)
$M E(\mathrm{MJ} / \mathrm{Kg})=2.20+0.136 \mathrm{GV}+0.057 C P$
(Blümmel and Ørskov, 1993)
$D M I(\mathrm{~kg} /$ day $)=1.66+0.49 a+0.0297 b-4 c$
(Makkar, 2005)
$\operatorname{SCFA}(\mathrm{mmol} / \mathrm{L})=0.0222 \mathrm{GV}-0.00425$

Where: GV is gas production after 24 hours, $C P$ is crude protein and $X A$ ash content of the processed form of croton, $a, b$ and $c$ are constants as described in Equation 1.

\section{In sacco degradation (nylon bag technique)}

In sacco degradation of the various forms of croton was carried out using Nylon bag technique as described by Ørskov (2000). Two mature fistulated Friesian steers weighing $450 \pm 25 \mathrm{~kg}$ live weight were used. The steers were fed on Rhodes grass (Chloris gayana) hay and wheat bran at $90 \%$ and $10 \%$ respectively of the total ration at $3 \%$ of their body weight at 08:00 hours and 17:00 hours for maintanance purposes. Mineral licks and water were provided adlibitum. This was done so as to maintain a stable rumen environment. Five grams of each processed sample of croton was weighed into duplicate nylon bags $(12 \mathrm{~cm}$ by $6 \mathrm{~cm}, 50 \mu \mathrm{m}$ pore size). The bags were incubated for $0,9,12,16,24,48$ and 72 hours in the rumen. Zero-hour washing was measured by soaking nylon bags containing the sample in water maintained at 39 ${ }^{\circ} \mathrm{C}$ for 1 hour. Bags from zero hour washing and those retrieved from the rumen were washed thoroughly under running cold water for 15 minutes until the washing water was clear. The bags with the residue were then dried at $60^{\circ} \mathrm{C}$ for 48 hours in a forced air oven and dry matter loss determined as the difference from the original weight. Crude protein and neutral detergent fibre (NDF) from the residue were then analysed. The DM, CP and NDF degradability characteristics were determined by fitting the degradability data to the exponential Equation 6 of Ørskov and Mcdonald (1979) using Neway Excel Computer program (Chen X. B., Rowett Research Institute, Aberdeen UK).

$$
P=a+b\left(1-e^{-c t}\right) \quad \text { (Ørskov and Mcdonald, 1979) }
$$

Where: $P$ is the degradability of (DM, CP and NDF) incubated in the rumen at time $t$ in hours, $a$ is the percentage of rapidly soluble fraction, $b$ is the percentage of insoluble but fermentable fraction, $a+b$ is potential percentage of degradability, $c$ is the rate of constant degradation per hour $\left(\mathrm{h}^{-1}\right)$ and $e$ is the exponential constant (2.718).

Effective degradability (ED) of DM, CP and NDF was calculated using Equation (7).

$$
\begin{array}{ll}
E D & =a+b\left(\frac{c}{c+k p}\right) \\
\text { (McDonald, 1981) }
\end{array}
$$

Where: $a+b$ is the potential degradability, $c$ is the rate constant degradability per hour $(\mathrm{h}), \mathrm{kp}$ is the ruminal outflow rate. The following outflow rates $(k p)$ per hour were considered $(0.025,0.05$ and 0.08$)$. Rumen undegradable protein (RUP) was calculated by subtracting effective degradable CP\% from $100 \%$. The DM index value (IV) which denotes the fraction of the feed that would provide nutrients to the animal for its maintenance needs was calculated using Equation 8. A feed with an index value above 33 would provide sufficient nutrients to the animal for its maintenance needs.

$I V=a+0.4 b+200 c$ Ørskov and Shand (1997) (8)

Where: $a, b$ and $c$ are as described in Equation 6.

\section{Statistical analysis}

Analysis of variance (ANOVA) was carried out on proximate composition, fibre fractions, minerals composition, gross energy (GE) and phytochemicals as well as in vitro gas production and in sacco degradability parameters. The analysis was based on completely randomized design using STATA (2017). Significant differences between the means were tested using Tukey's honest significance difference (THSD). The following statistical model was used

$$
y_{i j}=\mu+f_{i}+e_{i j}
$$


Where: $y_{i j}=$ chemical composition, in vitro gas production and in sacco degradability parameters, $\mu=$ mean of the different forms of Croton megalocarpus, $f_{i}=$ forms of croton nuts ( $i=W N$, PN, DhN and DfS), $e_{i j}=$ error term.

Ethical approval

All process of in vivo study was in according to animal welfare rules and approved by university ethical committee.

\section{RESULTS}

\section{Proximate composition}

Proximate composition of the various forms of croton nut is presented in Table 1. Peeled nut had significantly high DM content while WN did not differ significantly from DhN and DfS $(P<0.05)$. Defatted seeds had significantly high $C P$ content compared to other forms while the lowest level of CP was recorded in WN and PN which were not significantly different $(P<0.05)$. The CF content was significantly low in $\mathrm{DhN}$ compared to the other forms while the ash content was significantly high in WN followed by DfS, but no significant difference was observed between PN and DhN. The EE content did not differ significantly between WN and PN but was significantly high in DhN at $363 \mathrm{~g} / \mathrm{kg}$ and significantly low in DfS $(113 \mathrm{~g} / \mathrm{kg}$; P<0.05). The NFE in all forms did not differ significantly. Gross energy was highest in the $\mathrm{DhN}(21.1 \mathrm{MJ} / \mathrm{kg})$ and lowest in PN (17.3MJ/Kg) although the differences were not significant.

\section{Fibre composition}

Fibre composition of the various forms of croton nut is presented in Table 2. Processing by dehusking and defatting resulted to lower NDF content in DhN and DfS to $576 \mathrm{~g} / \mathrm{kg}$ and $556 \mathrm{~g} / \mathrm{kg}$ respectively, compared to WN and PN forms $(P<0.05)$. Hemicellulose content was highest in $P N(205 \mathrm{~g} / \mathrm{kg})(P<0.05)$. The cellulose level ranged between $94 \mathrm{~g} / \mathrm{kg}$ in DhN to $181 \mathrm{~g} / \mathrm{kg}$ in WN. The NDICP ranged between 16 in PN to 24 in DfS while ADICP ranged between 16 to 21 in both WN and DfS $(P>0.05)$. There were no significant differences in ADF, ADL, cellulose, NDICP and ADICP among the croton forms $(P>0.05)$.

\section{Table 1 - Proximate composition of the various forms of croton nut (g/kg)}

\begin{tabular}{lcccccc}
$\begin{array}{l}\text { Nutritional } \\
\text { parameter }\end{array}$ & $\begin{array}{c}\text { Whole nut } \\
(\text { WN) }\end{array}$ & $\begin{array}{c}\text { Peeled nut } \\
(\text { PN) }\end{array}$ & $\begin{array}{c}\text { Dehusked nut } \\
(\text { DhN) }\end{array}$ & $\begin{array}{c}\text { Defatted seeds } \\
\text { (DfS) }\end{array}$ & SEM & Prob. \\
\hline Dry matter & $893^{a}$ & $963^{b}$ & $917^{c}$ & $919^{c}$ & 0.763 & $P<0.001$ \\
Crude protein & $89^{a}$ & $80^{a}$ & $158^{b}$ & $198^{c}$ & 1.487 & $P<0.001$ \\
Crude fibre & $522^{a}$ & $579^{b}$ & $336^{c}$ & $476^{a}$ & 2.747 & $P<0.001$ \\
Ether extract & $185^{a}$ & $175^{a}$ & $363^{b}$ & $113^{c}$ & 2.824 & $P<0.001$ \\
Ash & $59^{a}$ & $23^{b}$ & $24^{b}$ & $38^{c}$ & 0.449 & $P<0.001$ \\
Nitrogen free extract & $143^{\mathrm{a}}$ & $143^{\mathrm{a}}$ & $120^{\mathrm{a}}$ & $174^{\mathrm{a}}$ & 0.847 & $\mathrm{P}<0.001$ \\
Gross energy (MJ/kg) & 18.1 & 17.3 & 21.1 & 19.3 & 0.826 & $\mathrm{NS}$ \\
\hline
\end{tabular}

a,b,c; Means in the same row without common letter are different at $\mathbf{P}<0.05$; SEM = standard error of the mean; Prob.= probability; NS = not significant.

\section{Table 2 - Fibre composition of the various forms of croton nut $(\mathrm{g} / \mathrm{kg})$}

\begin{tabular}{|c|c|c|c|c|c|c|}
\hline Fibre components & Whole nut (WN) & Peeled nut (PN) & $\begin{array}{c}\text { Dehusked nut } \\
\text { (DhN) }\end{array}$ & $\begin{array}{c}\text { Defatted seeds } \\
\text { (DfS) }\end{array}$ & SEM & Prob. \\
\hline NDF & $686^{a}$ & $741^{a}$ & $576^{b}$ & $556^{b}$ & 2.36 & $P<0.001$ \\
\hline ADF & 506 & 536 & 482 & 490 & 1.10 & 0.357 \\
\hline ADL & 341 & 377 & 392 & 367 & 1.62 & 0.781 \\
\hline Hemicellulose & $180^{\mathrm{ab}}$ & $205^{b}$ & $94^{\mathrm{ac}}$ & $66^{c}$ & 2.02 & $P<0.010$ \\
\hline Cellulose & 181 & 168 & 94 & 132 & 1.39 & 0.089 \\
\hline NDICP & 22 & 16 & 23 & 24 & 0.159 & 0.155 \\
\hline ADICP & 21 & 16 & 17 & 21 & 0.115 & 0.063 \\
\hline
\end{tabular}

\section{Minerals composition}

Mineral content of the various forms of croton nut is presented in Table 3. Processing by defatting enhanced the macro minerals (Ca, $\mathrm{P}, \mathrm{Mg}$ and $\mathrm{Na})$ in $\mathrm{DfS}(\mathrm{P}<0.05)$. Whole nut recorded the highest level of potassium $(14.27 \mathrm{~g} / \mathrm{Kg})$ 


\begin{tabular}{|c|c|c|c|c|c|c|}
\hline Mineral composition & $\begin{array}{l}\text { Whole nut } \\
\text { (WN) }\end{array}$ & $\begin{array}{l}\text { Peeled nut } \\
\text { (PN) }\end{array}$ & $\begin{array}{l}\text { Dehusked nut } \\
\text { (DhN) }\end{array}$ & $\begin{array}{c}\text { Defatted seeds } \\
\text { (DfS) }\end{array}$ & SEM & Prob. \\
\hline \multicolumn{7}{|l|}{ Macro minerals } \\
\hline Calcium & $1.51^{a}$ & $1.69 \mathrm{ab}$ & $1.82^{\mathrm{ab}}$ & $2.13^{b}$ & 0.084 & 0.0324 \\
\hline Phosphorus & $3.21^{\mathrm{ab}}$ & $2.78^{a}$ & $4.21^{b c}$ & $5.04^{c}$ & 0.284 & $<0.001$ \\
\hline Magnesium & $0.46^{a b}$ & $0.35^{a}$ & $0.57 \mathrm{bc}$ & $0.71^{c}$ & 0.042 & $<0.001$ \\
\hline Sodium & $0.79 a$ & $0.14^{b}$ & $0.34 c$ & $2.27^{d}$ & 0.251 & $<0.001$ \\
\hline Potassium & $14.27^{a}$ & $4.36^{b}$ & $3.66^{b}$ & $5.41^{c}$ & 1.294 & $<0.001$ \\
\hline \multicolumn{7}{|l|}{ Micro minerals } \\
\hline Iron & $0.113^{a}$ & $0.051^{b}$ & $0.063^{b c}$ & $0.075^{c}$ & 0.0071 & $<0.001$ \\
\hline Manganese & $0.024^{a}$ & $0.029 a$ & $0.047^{b}$ & $0.046^{b}$ & 0.0031 & $<0.001$ \\
\hline Zinc & $0.022^{a b}$ & $0.017^{a}$ & $0.034^{b c}$ & $0.049 c$ & 0.004 & 0.001 \\
\hline Copper & 0.007 & 0.015 & 0.019 & 0.008 & 0.0027 & 0.401 \\
\hline
\end{tabular}

\section{Phytochemicals and aflatoxin content}

Phytochemical composition and aflatoxin levels of the various forms of croton nut is presented in Table 4. Flavonoid content in WN was significantly higher $(124 \mathrm{~g} / \mathrm{kg})(\mathrm{P}<0.05)$ from other forms. Alkaloids ranged from $60 \mathrm{~g} / \mathrm{kg}$ in $\mathrm{DfS}$ to $69 \mathrm{~g} / \mathrm{kg}$ in WN $(P>0.05)$. Both WN and DfS had the highest tannin level $(9.6 \mathrm{~g} / \mathrm{kg})(P<0.05)$. Aflatoxin level was highest in DhN (21.1 ppb) and least in PN (6.4 ppb).

\section{In vitro gas production}

In vitro gas production fermentation characteristics of the various forms of croton nut are presented in Table 5. There was no difference in gas production from the readily soluble fraction (a) among the forms $(P>0.05)$. However, highest gas production of $(b)$ and $(a+b)$ were observed in DfS at $(18.6 \mathrm{ml})$ and $(22.2 \mathrm{ml})$ respectively $(P<0.05)$. Defatted seeds recorded the highest OMD (41.0\%), ME (5.9 MJ/kg), and SCFA $(0.419 \mathrm{mmol} / \mathrm{L})$ while PN had the least OMD (29.8\%), ME (4.3 MJ/kg) and SCFA (0.271 mmol/L).

\section{In sacco DM degradability}

In sacco DM degradability characteristics of the various forms of croton nut are presented in Table 6. Dehusked nut had highest rapidly soluble DM fraction $(a \sim 42.8 \%)$ and potentially degradable DM fraction $(a+b \sim 58.4 \%)(P<0.05)$, with the rate constant of degradation (c) ranging between 0.02 in WN to 0.2 in DhN. Effective dry matter degradability (EDDM) among the various forms was observed to reduce as the rumen outflow rate increased. Dehusked nut (DhN) had consistently higher percentages of EDDM and at all rumen outflow rates and a converse trend was true for PN. Dehusked nut also recorded the highest IV $90.1(P<0.05)$.

\section{In sacco CP degradability}

In sacco CP degradability characteristics of the various forms of croton nut are presented in Table 7. Rapidly degradable fraction of protein (a) was highest in WN (4.1\%) $(P<0.05)$. At $p<0.05$, slowly degradable fraction $(b)$ and potential degradable fraction $(a+b)$ were highest in $\mathrm{DhN}(87.8 \%)$ and $(87.9 \%)$ and lowest in WN (59.4\%) and (63.5\%) respectively. The rate constant of degradability per hour (c) was highest in PN (0.26) and lowest in DhN (0.02) whereas highest rumen undegradable protein was recorded in WN (36.4\%) and the lowest recorded in DhN (12.0\%). At $k p=0.025$, effective degradable crude protein for $\mathrm{DhN}(80.0 \%)$ and $\mathrm{DfS}(65.1 \%)$ were different $(\mathrm{P}<0.05)$ from that of WN and PN. The rumen undegradable protein (RUP) among all forms of croton nuts at $0.025 \mathrm{kp}$ was low compared to RUP at $0.05 \mathrm{kp}$ and $0.08 \mathrm{kp}(\mathrm{P}<0.05)$.

\section{In sacco NDF degradability}

The NDF degradability characteristics of the various forms of croton nut are presented in Table 8. Significant difference in NDF degradability was observed in rapidly degradable fraction (a) which was highest in DhN (17.2\%) compared to the other forms of croton nut $(P<0.05)$. There was no significant difference among the various forms of croton nut for $b, a+b$, and $c$. At $0.025 \mathrm{kp}$ and $0.08 \mathrm{kp}$, effective degradability NDF was significantly high in DhN compared to the other forms. However, at $0.05 \mathrm{kp}$ there was no significance difference among all forms of croton nut in EDNDF. 
Table 4 - Phytochemical and aflatoxin content of the various forms of croton nut $(\mathrm{g} / \mathrm{kg})$.

\begin{tabular}{lcccccc} 
Anti-nutritive factors & $\begin{array}{c}\text { Whole nut } \\
(\mathbf{W N})\end{array}$ & $\begin{array}{c}\text { Peeled nut } \\
(\mathrm{PN})\end{array}$ & $\begin{array}{c}\text { Dehusked nut } \\
(\mathrm{DhN})\end{array}$ & $\begin{array}{c}\text { Defatted seeds } \\
\text { (DfS) }\end{array}$ & SEM & Prob. \\
\hline Flavonoids & $124^{\mathrm{a}}$ & $57^{\mathrm{b}}$ & $43^{\mathrm{b}}$ & $64^{\mathrm{b}}$ & 1.01 & P<0.0014 \\
Alkaloids & 69 & 67 & 62 & 60 & 1.85 & 0.307 \\
Tannins & $9.6^{\mathrm{a}}$ & $7.1^{\mathrm{b}}$ & $8.9^{\mathrm{ab}}$ & $9.6^{\mathrm{a}}$ & 0.04 & P<0.021 \\
Aflatoxin (ppb) & 14 & 6.4 & 21.1 & 9.9 & 3.13 & ND \\
\hline a,b,c; Means in the same row without common letter are different at (P<0.05); SEM = standard error of the mean; Prob. = probability; ND = not
\end{tabular}
determined.

Table 5 - In vitro gas production of the various forms of croton nut ( $\mathrm{ml} \mathrm{gas} / 0.2 \mathrm{~g}$ dry matter).

\begin{tabular}{|c|c|c|c|c|c|c|}
\hline Gas production parameters & $\begin{array}{l}\text { Whole nut } \\
\text { (WN) }\end{array}$ & $\begin{array}{l}\text { Peeled nut } \\
\text { (PN) }\end{array}$ & $\begin{array}{l}\text { Dehusked nut } \\
\text { (DhN) }\end{array}$ & $\begin{array}{c}\text { Defatted seeds } \\
\text { (DfS) }\end{array}$ & SEM & Prob. \\
\hline$a$ & 1.4 & 4.2 & 2.4 & 3.7 & 0.465 & $P<0.083$ \\
\hline$b$ & $18.6^{a}$ & $10.6^{b}$ & $14.3^{\mathrm{ab}}$ & $18.4^{a}$ & 1.28 & $P<0.004$ \\
\hline$a+b$ & $20.1^{\mathrm{ab}}$ & $14.9^{a}$ & $16.8^{\mathrm{ab}}$ & $22.2^{b}$ & 1.13 & $P<0.019$ \\
\hline c & 0.08 & 0.06 & 0.10 & 0.08 & 0.007 & $P<0.096$ \\
\hline OMD & $34.1^{\mathrm{ab}}$ & $29.8^{a}$ & $35.3^{b}$ & $41.0^{c}$ & 1.54 & $P<0.004$ \\
\hline ME (MJ/Kg) & $5.0^{\mathrm{a}}$ & $4.3^{\mathrm{a}}$ & $5.1^{\mathrm{a}}$ & $5.9^{b}$ & 0.218 & $P<0.005$ \\
\hline DMI (kg/day) & 2.6 & 3.8 & 2.8 & 3.6 & 0.226 & $P<0.103$ \\
\hline SCFA (mmol/L) & $0.37^{a}$ & $0.27^{\mathrm{ab}}$ & $0.32^{\mathrm{ab}}$ & $0.41^{b}$ & 0.022 & $P<0.035$ \\
\hline
\end{tabular}

Table 6 - In sacco DM degradability characteristics for various forms of croton nut (\%).

\begin{tabular}{|c|c|c|c|c|c|c|}
\hline $\begin{array}{l}\text { DM degradability } \\
\text { parameters }\end{array}$ & $\begin{array}{l}\text { Whole nut } \\
\text { (WN) }\end{array}$ & $\begin{array}{l}\text { Peeled nut } \\
\text { (PN) }\end{array}$ & $\begin{array}{c}\text { Dehusked nut } \\
\text { (DhN) }\end{array}$ & $\begin{array}{c}\text { Defatted } \\
\text { seeds (DfS) }\end{array}$ & SEM & Prob \\
\hline$a$ & $29.5^{\mathrm{a}}$ & $26.4^{\mathrm{b}}$ & $42.8^{c}$ & $33.4^{\mathrm{d}}$ & 2.33 & $P<0.001$ \\
\hline$b$ & $18.8^{\mathrm{ab}}$ & $22.5^{b}$ & $15.6^{\mathrm{ab}}$ & $12.5^{a}$ & 1.49 & $P<0.028$ \\
\hline$a+b$ & $48.3^{a}$ & $49.0^{a}$ & $58.4^{b}$ & $46.0^{a}$ & 1.87 & $P<0.011$ \\
\hline c & 0.02 & 0.01 & 0.20 & 0.05 & 0.032 & $P<0.051$ \\
\hline EDDM $(k p=0.025)$ & $37.8^{a}$ & $30.7^{b}$ & $56.6^{c}$ & $41.8^{d}$ & 3.56 & $P<0.001$ \\
\hline $\operatorname{EDDM}(k p=0.05)$ & $34.9^{a}$ & $28.8^{b}$ & $55.1^{c}$ & $39.7^{d}$ & 3.68 & $P<0.001$ \\
\hline EDDM $(k p=0.08)$ & $33.2^{a}$ & $28.0^{b}$ & $53.8^{c}$ & $38.3^{d}$ & 3.64 & $P<0.001$ \\
\hline IV & $41.0^{a}$ & $36.6^{a}$ & $90.1^{\mathrm{b}}$ & $48.5^{a}$ & 8.44 & $P<0.017$ \\
\hline
\end{tabular}

$a, b, c, d ;$ Means in the same row without common letter are different at $P<0.05 ; a=$ is the rapidly soluble fraction; $b=$ is the insoluble but fermentable fraction; $a+b=$ is the potentially degradable fraction; $c=$ is the rate constant of degradation; IV $=$ index value; EDDM = effective degradability of dry matter; $\mathrm{kp}=$ rumen outflow rate; SEM = standard error of the mean; Prob. = probability.

Table 7 - In sacco CP degradability characteristics of the various forms of croton nut (\%).

\begin{tabular}{|c|c|c|c|c|c|c|}
\hline CP degradability & $\begin{array}{l}\text { Whole nut } \\
\text { (WN) }\end{array}$ & $\begin{array}{l}\text { Peeled nut } \\
\text { (PN) }\end{array}$ & $\begin{array}{c}\text { Dehusked nut } \\
\text { (DhN) }\end{array}$ & $\begin{array}{c}\text { Defatted } \\
\text { seeds (DfS) }\end{array}$ & SEM & Prob. \\
\hline $\bar{a}$ & $4.1^{a}$ & $0.02^{b}$ & $0.08^{b}$ & $0.4^{b}$ & 0.660 & $P<0.002$ \\
\hline$b$ & $59.4^{a}$ & $75.0^{b}$ & $87.8^{c}$ & $74.7^{b}$ & 3.81 & $P<0.001$ \\
\hline$a+b$ & $63.5^{a}$ & $75.0^{b}$ & $87.9^{c}$ & $75.1^{b}$ & 3.26 & $P<0.001$ \\
\hline c & $0.06^{a}$ & $0.26^{b}$ & $0.02^{b}$ & $0.16^{c}$ & 0.0312 & $P<0.001$ \\
\hline $\operatorname{EDCP}(k p=0.025)$ & $46.2^{a}$ & $68.5^{a}$ & $80.0^{b}$ & $65.1^{b}$ & 4.59 & $P<0.001$ \\
\hline $\operatorname{EDCP}(k p=0.05)$ & $36.8^{a}$ & $63.0^{b}$ & $73.5^{c}$ & $57.5^{d}$ & 5.06 & $P<0.001$ \\
\hline $\operatorname{EDCP}(k p=0.08)$ & $29.8^{a}$ & $57.4^{b}$ & $66.9 c$ & $50.4^{d}$ & 5.16 & $P<0.001$ \\
\hline $\operatorname{RUP}(k p=0.025)$ & $53.7^{a}$ & $31.4^{a}$ & $19.9^{b}$ & $34.8^{b}$ & 4.59 & $P<0.001$ \\
\hline $\operatorname{RUP}(k p=0.05)$ & $63.1^{a}$ & $36.9^{b}$ & $26.4^{c}$ & $42.4^{d}$ & 5.06 & $P<0.001$ \\
\hline $\operatorname{RUP}(k p=0.08)$ & $70.1^{a}$ & $42.5^{b}$ & $33.0^{c}$ & $49.5^{d}$ & 5.16 & $P<0.001$ \\
\hline
\end{tabular}


Table 8 - In sacco NDF degradability characteristics of the various forms of croton nuts (\%)

\begin{tabular}{|c|c|c|c|c|c|c|}
\hline NDF degradability & $\begin{array}{l}\text { Whole nut } \\
\text { (WN) }\end{array}$ & $\begin{array}{l}\text { Peeled nut } \\
\text { (PN) }\end{array}$ & $\begin{array}{c}\text { Dehusked nut } \\
\text { (DhN) }\end{array}$ & $\begin{array}{c}\text { Defatted } \\
\text { seeds (DfS) }\end{array}$ & SEM & Prob. \\
\hline $\bar{A}$ & $6.5^{\mathrm{a}}$ & $2.0^{\mathrm{a}}$ & $17.2^{\mathrm{b}}$ & $1.6^{a}$ & 2.41 & 0.002 \\
\hline$B$ & 15.1 & 9.4 & 10.1 & 15.8 & 1.28 & 0.144 \\
\hline$a+b$ & 21.6 & 11.4 & 27.3 & 17.4 & 2.44 & 0.065 \\
\hline C & 0.03 & 0.01 & 0.33 & 0.35 & 0.0052 & 0.714 \\
\hline EDNDF $(k p=0.025)$ & $15.0^{\mathrm{a}}$ & $5.9^{b}$ & $22.9^{c}$ & $9.1^{b}$ & 2.47 & $P<0.001$ \\
\hline EDNDF $(k p=0.05)$ & 11.2 & 7.5 & 21.2 & 6.8 & 2.45 & 0.053 \\
\hline EDNDF $(k p=0.08)$ & $10.2^{a}$ & $3.7^{\mathrm{b}}$ & $20.1^{c}$ & $5.5^{b}$ & 2.43 & $P<0.001$ \\
\hline
\end{tabular}

\section{DISCUSSION}

\section{Nutritional composition}

The DM content in all forms was above $86 \%$, which is the recommended level for storage of feeds. Conversely, this implied low moisture content that is critical in preventing growth of fungi and reducing aflatoxin contamination (Mahato et al., 2019). The high moisture content in WN suggests that the peel acts as a barrier against loss and itself contains moisture. Whole nuts and DfS had high ash contents indicating that they could be good sources of minerals for grazing animals during the dry seasons hence averting the effects of mineral deficiencies such as impaired growth, poor health and reduced reproductive performance in ruminants (Lengarite et al., 2012). This is corroborated by mineral results whereby, $\mathrm{Ca}$ and $\mathrm{P}$ levels of all forms of croton nut in this study were within the recommended critical maintenance level $(1.2-2.6 \mathrm{~g} / \mathrm{kg} \mathrm{Ca})$ and $(1.4 \mathrm{~g} / \mathrm{kg} \mathrm{P})$ respectively for ruminant animals (ARC, 1980). The $\mathrm{K}$ level in WN was above $8 \mathrm{~g} / \mathrm{kg}$ even though, the $\mathrm{Mg}$ level in all forms was below $(2 \mathrm{~g} / \mathrm{kg}$ ) recommended level for grazing animals, (Mirzaei, 2012). The level of Fe was above the recommended level $(0.05 \mathrm{~g} / \mathrm{kg})$ for grazing animals (ARC, 1980). Both DhN and DfS contained the recommended critical level of $\mathrm{Zn}(0.03 \mathrm{~g} / \mathrm{kg})$ which is sufficient for cattle, sheep and goats (ARC, 1980).

Removal of the husks and defatting effectively elevated CP content as reflected in DhN and DfS forms. The CP in all croton forms was above the recommended $(80 \mathrm{~g} / \mathrm{kg}$ ) required for maintenance in grazing ruminant animals (NRC, 2001). Moreover, DhN and DfS CP levels were within $140 \mathrm{~g} / \mathrm{kg}$ to $165 \mathrm{~g} / \mathrm{kg}$ recommended for growth and increased milk production in lactating animals (NRC, 2001). Defatting reduced the EE content considerably in DfS making it suitable for storage by reducing the amount of oils which when oxidised cause rancidity hence feed spoilage.

Removal of the outer peel and husks (hard woody endocarp encasing the seeds) lowered the fibre levels considerably in DhN and DfS. Neutral detergent fibre level in these forms was between $450 \mathrm{~g} / \mathrm{kg}$ to $650 \mathrm{~g} / \mathrm{kg}$. These forms may be classified as medium quality feed, a predominant characteristic of tropical feed stuffs (Singh and Oosting, 1992). Feeds in this category can achieve the required gut health of ruminant animals by enhancing optimum feed intake, stimulating rumen function and increasing chewing of cud (Singh and Oosting, 1992). Moderate crude protein levels $(80-90 \mathrm{~g} / \mathrm{kg})$ in WN and PN could play a fundamental role in mitigating lowered fibre digestibility that may be occasioned by the high NDF through availing of rumen ammonia nitrogen necessary for optimal functioning of the rumen ecosystem (Van Soest, 1994). There was no difference in NDICP among all forms of croton nut an indication that the degradability of insoluble-protein fraction was similar in all forms. NDICP represent the insoluble fraction of protein that remains after extraction with neutral detergent solution and is usually assumed to be insoluble (Mustafa et al., 2001). This fraction is a measure of nitrogen availability and constitutes a major portion of ruminal undegradable protein content (Mustafa et al., 2001).

High flavonoid content in all forms of croton nuts is an indication that croton nut could be included in ruminant feed rations to confer improved growth performance, health and improved rumen fermentation (Panche et al., 2016). A study by Kong et al. (2019) showed that flavonoid supplementation improved the average daily gain by alleviating stress during weaning of Holstein calves. Low level of tannins $(<50 \mathrm{~g} / \mathrm{kg})$ similar to those recorded in this study could confer beneficial effects to ruminant animals such as reduction in ruminal protein degradation thus availing essential amino acids for absorption in the small intestines (Frutos et al., 2004). The level of aflatoxin observed in this study was within the minimum recommended level of $20 \mathrm{ppb}$ for complete and complementary feed materials used for feeding cattle, sheep and goats except for DhN (Kotinagu et al., 2015). The high level of aflatoxin in DhN could be attributed to high level of oil which provides conducive environment for growth of fungi resulting in production of aflatoxins (Filazi and Sireh, 2013). Therefore, proper handling and storage of $\mathrm{DhN}$ is crucial to prevent conditions that could encourage growth of fungi.

\section{In vitro gas production}

Amount of gas produced in in vitro gas digestibility method is an indicator of the rate and extent of feed digestion (Makkar, 2005). Gas production is affected by the composition, bioavailability of nutrients and presence of anti-nutritive factors in a feed. The higher levels of gas production observed in DfS compared to other forms of croton could be 
attributed to high levels of fermentable carbohydrates and protein which produce more gas when acted upon by rumen microbes (Makkar, 2005). Quality of roughage in a feed determines the nutritive value that the feed would confer when fed to an animal. The presence of high amount of fibre in a feed increases the rumen pool of indigestible fibre lignin which impedes the action of fibrolytic microbes that act on cellulose and hemicellulose (Venkateswarlu et al., 2013). This consequently reduces fermentable fibre as observed in PN.

Observed reduced fermentation characteristics in $\mathrm{DhN}$ could be attributed to high levels of EE in this form. Although the type of fat was not differentiated in present study, presence of poly unsaturated fatty acids (PUFA) has been shown to reduce activity of fibre degrading microbes resulting to lower degradation and low gas production as observed in this study (Maia et al., 2010). It has been shown that excess oil of the long fatty acids in a feed (more than $3-5 \%$ ) of the dry matter has a toxic effect on ruminal microorganisms especially bacteria which form the major fibrolytic colonies (CastilloGonzáleza et al., 2014). High predicted OMD and DMI in DfS implied better nutritive value in this form indicating that ruminant animals could consume higher amounts compared to the other forms (Negesse et al., 2016). The markedly high level of SCFA produced by DfS indicated that this form was better placed to supply the ruminant animals with the requisite energy to support production.

\section{In sacco degradability}

High dry matter degradability of rapidly degradable fraction (a) in $\mathrm{DhN}$ is an indication of high soluble nutrients which could be combined with low quality roughages to provide protein and energy needed by microbes. Slowly degradable fraction (b) of DM in all forms of croton nut was low compared to rapidly degradable fraction. Low fibre quality limit the ability of microbes in effectively degrading the feed by making it difficult for rumen microorganism to attach on the feed particles (Venkateswarlu et al., 2013). The dry matter rate constant of degradation (c) was comparable to various conventional feed resources such as coconut meal, peanut meal and whole cotton seeds (0.2-0.05 per hour) (Chumpawadee et al., 2005). This rate is important as it determines rumen fill and exerts direct effect on intake (Chumpawadee et al., 2005). At rumen outflow rate of $k p=0.05$, effective degradability (DM) of various forms of croton in this study were within the range (24.3 - 60.9\%) observed for conventional protein sources which include soy bean meal, whole cotton seed, coconut meal and fish meal (Chumpawadee et al., 2005). This fraction represents the total amount of nutrients which can be captured by rumen microbes for their growth, production of VFAs and synthesis of microbial protein (Lanyasunya et al., 2006). The IV of all croton forms in this study were within the acceptable level of $>33$ as recommended by (Ørskov and Shand 1997). This level indicates sufficient nutrients that an animal needs to consume to meet its daily maintenance needs.

The low level of rapidly soluble fraction of CP (a) observed in this study is within the recommended $<40 \%$ for effective degraded protein (Lanyasunya et al., 2006). At this level, the (a) fraction does not overwhelm rumen microbes through production of excess nitrogen in form of ammonia, thus, maintaining an optimal protein-energy balance. Feeds with high slowly degradable fraction $(b)$ avail required nitrogen in small amounts which are effectively utilized by rumen microbes. Effective degradability of crude protein provides an estimate of the total amount of protein captured by the rumen microbes for growth and synthesis of microbial protein (Lanyasunya et al., 2006). This fraction was high in DhN an indication that a considerable amount of protein in this form was degraded in the rumen. The remaining amount of protein regarded as rumen undegradable protein (RUP) represents the fraction of protein that is not degraded in the rumen and is termed as rumen by pass protein (Gao et al., 2015). Rumen by pass protein is available at the lower gut (small intestines) where combined with microbial protein contribute to protein requirements of the animal for maintenance and production. In this study WN was a good source of RUP and could be used to provide this form of protein in ruminant diets.

\section{CONCLUSION}

Processing through dehusking and defatting had the most significant impact on the nutritional composition of croton nuts. The two methods improved the nutritional profiles of protein, energy and mineral contents while reducing the fibre fractions compared to where peeling or no-processing was done. Degradability of dehusked and defatted forms of croton nuts was also high compared to the peeled and unprocessed whole nut forms. However, nutritional value of all forms of croton nuts was adequate and could be used in a total mixed ration (TMR) for maintenance purposes. In particular, dehusked and defatted forms have potential utilisation as protein supplements which could additionally supply energy and minerals for increased ruminant productivity on low quality basal diets. Microbial, enzymatic or chemical pre treatment of the WN and PN forms prior to feeding could be explored to improve any observed lowered feed digestibility. Further studies to assess the effect of feeding croton on palatability, level of intake and production performance of ruminants are required.

\section{DECLARATIONS}

\section{Corresponding author}

E-mail: wambuicc@gmail.com 


\section{Authors' contribution}

All authors contributed equally to this work.

\section{Conflict of interests}

The authors declare that there are no competing interests.

\section{Acknowledgements}

The authors thank Maseno University for provision of facilities to conduct the laboratory analyses, County Government of Laikipia for granting study leave to the first author and Kenya Climate Smart Agriculture Project (KCSAP) for funding this research.

\section{REFERENCES}

AOAC (1990). Official Methods of Analysis, Association of Analyitical Chemists. Arlington, Virginia (Vol. 1). Article link

ARC (1980). The Nurient Requirements of Ruminant Livestock Commonwealth. Farnham, Royal, UK. Article link

Blümmel M and Ørskov ER (1993). Comparison of an in vitro gas production and nylon bag degradability of roughages in predicting feed intake in cattle. Animal Feed Science and Technology, 40(2-3): 109-119. Article link I https://doi.org/10.1016/03778401(93)90150-I

Castillo-Gonzáleza AR, Burrola-Barrazab ME, Domínguez-Viverosb J and Chávez-Martínezb A (2014). Rumen microorganisms and fermentation. Archivos de Medicina Veterinaria, 46(3): 349-361. Article link I https://doi.org/10.4067/S0301732X2014000300003

Chumpawadee S, Sommart K, Vongpralub T and Pattarajinda V (2005). In Sacco Degradation Characteristics of Protein Feed Sources in Brahman-Thai Native Crossbred Steers. Walailak Journal of Science and Technology (WJST), 2(2): 219-229. Article link I https://doi.org/10.2004/wjst.v2i2.166

Filazi A and Sireh UT (2013). Occurence of Aflatoxin in Food -Aflatoxin - Recent Advances and Future. InTech Publication, Croatia. Article link I http://dx.doi.org/10.5772/51031

Frutos P, Hervás G, Giráldez FJ and Mantecón AR (2004). Review.Tannins and ruminant nutrition Tannins : structure and chemical. Spanish Journal of Agricultural Research, 2(2): 191-202. Article link

Gao W, Chen A, Zhang B, Kong P, Liu C and Zhao J (2015). Rumen degradability and post-ruminal digestion of dry matter , nitrogen and amino acids of three protein supplements. Asian Australasian Journal of Animal Science, 28(4): 485-493. Article link I https://dx.doi.org/10.5713\%2Fajas.14.0572

Harbone JB (1984). Phytochemical methods. Chapman Halls. New York. Article link

Herrero M, Grace D, Njuki J, Johnson N, Enahoro, D, Silvestri, S, and Rufino MC (2013) The roles of livestock in developing countries. Animal, 7(1): 3-18. Article link I https://doi.org/10.1017/S1751731112001954

Jacobson M, Shr YH, Dalemans F, Magaju C and Ciannella R (2018). Using a choice experiment approach to assess production tradeoffs for developing the croton value chain in Kenya. Forest Policy and Economics, 86: 76-85. Article link I https://doi.org/10.1016/j.forpol.2017.09.015

Kahi AK and Wasike CB (2019). Dairy goat production in sub-Saharan Africa : current status, constraints and prospects for research and development. Asian- Australasian Journal of Animal Science, 32(8): 1266-1274. Article link https://dx.doi.org/10.5713\%2Fajas.19.0377

KNBS (2019). Kenya population and housing census 2019 (distribution of population by socio-economic characteristics). Kenya Nationa Bureau of Statistics, Kenya. Article link

Kong L, Yang C, Dong L, Diao Q, Si B, Ma J and Tu Y (2019). Rumen fermentation characteristics in pre- and post-weaning calves upon feeding with mulberry leaf flavonoids and candida tropicalis individually. Animals 9(11): 990. Article link https://dx.doi.org/10.3390\%2Fani9110990

Kotinagu K, Mohanamba T and Kumari RL (2015). Assessment of aflatoxin B1 in livestock feed and feed ingredients by highperformance thin layer chromatography. Veterinary World, 8(12): 1396-1399. Article link | https://doi.org/10.14202/vetworld.2015.1396-1399

Lanyasunya TP, Rong Wang H, Abdulrazak S A, Mukisira E A, and Zhang J (2006). In sacco determination of dry matter, organic matte and cell wall degradation characteristics of common vetch (Vicia sativa L.). Tropical and Subtropical Agroecosystems, 6(2): 117123. Article link

Lengarite MI, Mbugua PN, Gachuiri CK, and Kabuage L W (2012). Mineral status of sheep and goats grazing in the arid rangelands of northern Kenya. Pakistan Journal of Nutrition, 11(4): 383-390. Article link I https://doi.org/10.3923/pjn.2012.383.390

Leszczyñska JO, Owska JO, Owczarek AL, and Kucharska UR (2001). Determination of Aflatoxins in Food Products by the ELISA Method. Czech Journal of Food Sciences, 19(1): 8-12. Article link I https://doi.org/10.17221/6567-CJFS

Mahato DK, Lee KE, Kamle M, Devi S, Dewangan KN, Kumar P and Kang S G (2019). Aflatoxins in Food and Feed: An Overview on Prevalence, Detection and Control Strategies. Frontiers in Microbiology, 10, 1-10. Article link https://doi.org/10.3389/fmicb.2019.02266

Maia MRG, Chaudhary LC, Bestwick CS, Richardson A, Mckain N, Larson T R, Graham I A and Wallace J (2010). Toxicity of unsaturated fatty acids to the biohydrogenating ruminal bacterium, Butyrivibrio fibrisolvens. BMC Microbiology, 10(52): 2-11. Article link I https://doi.org/10.1186/1471-2180-10-52

Makkar HPS (2005). In vitro gas methods for evaluation of feeds containing phytochemicals. Animal Feed Science and Technology, 123(124): 291-302. Article link | https://doi.org/10.1016/j.anifeedsci.2005.06.003

Makkar HPS (2014). Sustainable increase in livestock productivity in developing countries through efficient utilisation of feed resources. Cuban Journal of Agricultural Science, 48(1): 55-58. Article link

Makkar HPS and Becker K (1996). A bioassay for polyphenols (tannins). In Polyphenols communications (Vol. 96). Bordenaux France Article link

McDonald I (1981). A revised model for the estimation of protein degradability in the rumen. The Journal of Agricultural Science, 96(1): 
Menke HK and Steingass H (1988). Estimation of the energetic feed value obtained from chemical analysis and in vitro gas production using rumen fluid. Animal Research and Development, 28: 7-55. Article link

Mirzaei F (2012). Minerals Profile of Forages for Grazing Ruminants in Pakistan. International Journal of Livestock Research, 2(3): 133141. Article link I https://doi.org/10.5455/ijlr.20120407060608

MoALF (2017). Climate Risk Profile for Laikipia County. Kenya County Climate Risk Profile Series. The Minstry of Agriculture Livestock and Fisheries (MoALF), Nairobi, Kenya. Article link

Mustafa AF, Christensen DA and McKinnon JJ (2001). Ruminal degradability of neutral detergent insoluble protein of selected protein sources. Canadian Journal of Animal Science, 81(4): 601-603. Article link I https://doi.org/10.4141/A01-034

Nabarro D and Wannous C (2014). The potential contribution of livestock to food and nutrition security: the application of the One Health approach in livestock policy and practice. Revue Scientifique et Technique (International Office of Epizootics), 33(2): 475-485. Article link I https://www.oie.int/doc/ged/D14082.PDF

Ndegwa G, Moraa V and liyama M (2011). Potential for biofuel feedstock in Kenya. In World Agroforetsry Centre. Nairobi, Kenya. Article link

Negesse T, Merga B and Banerje S (2016). An In vitro Assessment of Supplementary Effect of Concentrates Containing Graded Levels of Ground Linseed (Linum Usitatissimum) To Household Wastes on Organic Matter Degradability, Short Chain Fatty Acids, Microbial Protein, Metabolizable Energy and Relat. Tropical and Subtropical Agroecosystems, 19 (2016): 181-191. Article link I CAB Direct

NRC (2001). Nutrient Requirements of Dairy Cattle National Research Council. In Nutrient Requirements of Dairy Cattle (7th ed.). National Academies Press, Canada. Article link

Ørskov ER (2000). The in situ technique for the estimation of forage degradability in ruminants. Forage Evaluation in Ruminant Nutrition, CABI Publishing, New York. Pp.175-188 . Google Scholar

Ørskov ER and Mcdonald I (1979). The estimation of protein degradability in the rumen from incubation measurements weighted according to rate of passage. The Journal of Agricultural Science, 92(2): 499-503. Article link I https://doi.org/10.1017/S0021859600063048

Ørskov ER and Shand WJ (1997). Use of the nylon bag technique for protein and energy evaluation and for rumen environment studies in ruminants. Livestock Research for Rural Development. 9: 1. Article link

Otte J, Pica-Ciamarra U and Morzaria S (2019). A comparative overview of the livestock-environment interactions in Asia and SubSaharan Africa. Frontiers in Veterinary Science, 6: 37. Article link I https://doi.org/10.3389/fvets.2019.00037

Panche AN, Diwan AD and Chandra SR (2016). Flavonoids: An overview. Journal of Nutritional Science, 5 (E47): 1-15. Article link I https://doi.org/10.1017/jns.2016.41

Quansah ES and Makkar HPS (2012). Use of lesser-known plants and plant parts as animal feed resources in tropical regions, FAO Animal Production and Health Working Paper, Issue 8 Rome, Italy Article link

Singh PG and Oosting SJ (1992). A model for describing the energy value of straws. Indian Dairyman, 44(1992): 322-327. Article link

STATA (2017). StataCorp statistics / Data/Analysis, Texas 77845 USA.

Thijssen RL, Temu AB, Melnyk M, and Vantomme P (1996). Croton megalocarpus, the poultry-feed tree: how local knowledge could help to feed the world. Proceedings of an International Conference 19-23 Feb 1996. Domestication and commercialization of non timber forest products in agro forestry systems. In Non-Wood Forest Products,pp. 226-234. Article link

Van Soest PJ (1994). Nutritional Ecology of the Ruminant. Comstock Publishing Associates. A diviosion of Cornell University Press. New York, USA. Article link

Van Soest PJ, Robertson JB and Lewis BA (1991). Methods for dietary fiber, neutral detergent fiber, and nonstarch polysaccharides in relation to animal nutrition. Journal of Dairy Science, 74(10): 3583-3597. Article link

Venkateswarlu S, Kumar DS and Rao ER (2013). degradation characteristics of legume straw based complete rations in the rumen using nylon bag technique degradation characteristics of legume straw based complete rations in the rumen using nylon bag technique. IOSR Journal of Agriculture and Veterinary Science, 3(4): 62-65. Article link 